\title{
Bølger italesætter oplevelsen af arbejdsdagen
}

\section{Sidse Grangaard}

I samarbejde med en tegnestue blev det muligt at udvikle og afprøve en involverende forundersøgelse i et designpilotprojekt i en kontorbygning. Ledelsen ville rive vægge ned for at understøtte videndeling og samarbejde, mens medarbejderne ønskede kontorer. Med udviklingen og anvendelsen af bølger som begreb til at fortælle om rytmen i arbejdsdagen, fik medarbejderne et sprog, som kunne italesætte oplevelsen af arbejdsdagen og de problemstillinger, de stod overfor. Mange skift i aktivitet og dermed mange små bølger var karakteristisk for mange af medarbejderne. Flere af dem drømte om at få flere længerevarende perioder med tid til alenearbejde i form af store bølger. Samtidig blev det muligt at få skabt et fælles billede af organisationen i designprocessen som udgangspunkt for diskussionen af løsninger i pilotprojektet.

$\mathrm{D}$ enne artikel vil på baggrund af en workspace design-case fra mit ph.d.projekt beskrive udviklingen af begrebet 'bølger' og argumentere for, at der med bølger og bølgeøvelsen som grænseobjekt er skabt et redskab til de workspace designprofessionelles værktøjskasser. Et redskab, som kan italesætte den individuelle oplevelse af arbejdsdagen og bidrage til et fælles billede af organisationen blandt workspace design-processens parter.

\section{Traditionelle \\ behovsafdækningsmetoder}

I en proces omkring design af et kontormiljø lægges der ofte en del energi i behovsafdækning og brugerinvolvering for at få skabt et grundlag for udarbejdelsen af et program og de efterfølgende løsninger. Forskellige metoder inden for kontordesign anbefales til behovsafdækning, primært udarbejdet i miljøet omkring den engelske tegnestue DEGW ${ }^{1}$ anført af Francis Duffy.
Der er gennemgående tale om tre typer: tilstedeværelsesregistrering, interviews og spørgeskemaundersøgelse. 'Time Utilization Studies' (Duffy 1997; Marmot \& Eley 2000; Blyth \& Worthington 2001) er en registrering af medarbejdernes tilstedeværelse og aktivitet i kontormiljøet en gang i timen. Den anbefales også i en dansk kontekst (Mosbech 2003), men det påpeges, at man bør overveje, hvornår det er relevant at igangsætte en registrering (Bjerrum \& Nielsen 2003). En tilstedeværelsesregistrering fortæller noget om, hvordan kontormiljøets kapacitet udnyttes og kan initiere en diskussion af, om kontormiljøet kan anvendes på en bedre måde. Dog fortæller registreringen ikke, hvad der sker imellem nedslagspunkterne og får derfor en statisk karakter frem for at fange dynamikken i organisationen og måden, kontormiljøet anvendes på (Grangaard 2008). Spørgeskemaundersøgelse betragtes som en måde at involvere medarbejderne på (Cuncliffe \& 
Raymond 1997). Medarbejdernes rolle er passiv, når de blot skal besvare et spørgeskema. De er leverandører af fakta, som andre fortolker, frem for at de involveres aktivt i processen og dermed får en stemme. Interview med ledelsen fremhæves for at få fokus på visioner og strategier i forhold til prioriteringen af medarbejdernes nærhedsønsker for at sikre, at det er de rigtige, der sidder sammen (Mosbech 2003). Når man ser på metoderne inden for kontordesign $\mathrm{i}$ tiåret omkring år 2000, er der et stort fokus på ledelsens visioner og fakta, som direkte kan oversættes til kvadratmetre og bestemte typer af indretning.

\section{Fraværet af et fælles billede og sprog}

I et ambitiøst nydesignet kontormiljø fra 2005 til en stor privat teknologisk udviklingsvirksomhed i Danmark, som i deres nye domicil valgte at fortsætte med at sidde i et åbent miljø, viste det sig, at medarbejderne anvendte kontormiljøet stik modsat af designkonceptet (Grangaard 2008). Noget tyder på, at der har været forskellige billeder af organisationen i spil. Den erfarne 'office space'-tegnestue havde udarbejdet et designkoncept, der baserede sig på deres tolkning og billede af organisationen samt en forventning om, hvordan et åbent kontormiljø fungerede. Den øverste ledelse havde godkendt et designkoncept, der passede til deres billede af organisationen, mens medarbejdernes billede af dem selv og deres arbejdspraksis var et andet. Til trods for disse forskellige billeder var resultatet et kontormiljø, som fungerede grundet de mange kvadratmetre og udbuddet af 'support'-faciliteter. Men ingen kan regne med at være så heldig hver gang. Det er tydeligt, at arkitektens billede ikke favnede den pågældende organisations arbejdspraksis. Noget tyder tillige på, at ingen af parterne har været bevidste om forskellene mellem billederne. De har troet, de talte samme sprog.

\section{Procesarkitekturens fokus på det fælles}

Inden for procesarkitekturen og forskningen på MIT i 1990'erne er der en opmærksomhed på, gennem fælles oplevelser, at understøtte udviklingen af et nyt sprog $\mathrm{i}$ en 'workplace design'-proces (Horgen et al. 1999). Redskabet 'structured events' danner sammen med indfaldsvinkel og interventionsstrategi rammen om et projekt. Indfaldsvinklen handler om at få skabt et godt samarbejde. 'Situational awareness' er en af de mest betydningsfulde interventionsstrategier, når det handler om at skabe en fælles bevidsthed blandt de involverede parter om problemstillingen og målet med en ny løsning.

\section{Grænseobjekter}

Grænseobjekter introduceres af Susan Leigh Star som betegnelse for objekter, repræsentationer eller begreber, der koordinerer og samordner perspektiver fra forskellige kontekster i et casestudie af samarbejdet mellem forskellige grupper ved the Museum of Vertebrate Zoology i Californien (Star \& Grisemer 1989). I en skandinavisk workspace-kontekst finder man blandt andet grænseobjekter som designdialoger i Sverige, hvor brugerne er meddesignere (Fröst 2004). Designdialoger er en form for metodisk tilgang, der baserer sig på de fire karakteristika, Etienne Wenger præsenterer: modularitet, abstraktion, tilpasningsevne og standardisering (Wenger 2004). 'Modularitet' dækker over, at flere perspektiver kan knyttes til et element. Eksempelvis består en avis af en mængde artikler, og principielt vil der være noget for enhver læser. 'Abstraktion' dækker over udeladte detaljer specifikke for nogle bestemte perspektiver. Et landkort viser eksempelvis kun nogle få egenskaber ved den virkelige verden. 'Tilpasningsevne' betyder, at grænseobjektet kan anvendes til forskellige aktiviteter. Et eksempel herpå er en kontorbygning, hvor 
rengøringspersonalet udøver en praksis, mens de ansatte hos lejeren af kontorbygningen udøver en anden praksis. 'Standardisering' betyder, at der er lagt føringer for, hvordan den information, der er knyttet til grænseobjekter, skal håndteres. Et eksempel herpå er en formular, der beskriver, hvorledes den skal udfyldes.

Grænseobjekterne står bogstaveligt talt ikke alene. Den kontekst, de bliver en del af, samt det slutprodukt, der generes ved at anvende et grænseobjekt, hænger sammen med grænseobjektet. (Broberg et al. 2010). Forfatterne udleder på baggrund af et dansk workspace-projekt en række karakteristika ved grænseobjekter, deres kontekst og slutprodukt. 'Facilitator stages and guides', 'rules and instructions', 'temporary learning space' og 'location' er fire karakterisktika angående kontekst. De handler alle om at få den planlagte intervention omkring grænseobjektet til at forløbe succesfuldt.

\section{Oplevelse af arbejdsdagen}

Arbejdspraksis handler ikke udelukkende om måden, der arbejdes på, men også om oplevelsen af arbejdsdagen. Der kan være forskel på medarbejderes beskrivelse af en arbejdsdag, og hvordan den faktisk forløber. Arbejdsopfattelsen udtrykker medarbejdernes 'arbejdstankesæt' (Bjerrum \& Aaløkke 2005). I nogle organisationer bliver alenearbejdet opfattet som det rigtige arbejde, og medarbejderne klager over, at de ikke får tid til at arbejde, fordi de bliver forstyrret af interaktion med kollegaer. Denne interaktion betragter de som en sekundær aktivitet (Bakke 2007). Men hvordan kan man tale om oplevelsen af arbejdsdagen? Vi har brug for et begreb, der kan blive en del af et fælles sprog, og som gør det muligt at kommunikere oplevelsen af arbejdsdagen. Dette behov er udgangspunktet for denne artikel.

\section{Metode og undersøgelsesdesign}

Inden for mange af designforskningens forskellige tilgange, eksempelvis procesarkitektur (Horgen et al. 1999) og DAIM Designantropologisk forskningsmodel (Halse et al. 2010) handler det om at udvikle designs gennem involvering af brugerne med afsæt i den opnåede viden fra etnografiske observationer eller brugernes egen fremstilling af deres hverdag eksempelvis i form af fotodagbøger.

"A major point in ethnographically inspired approaches is that work is a socially organized activity where the actual behaviour differs from how it is described by those who do it. This implies that detailed studies of work must include observations as well as interviews" (Simonsen \& Kensing 1997, 82).

I antropologien er det målet at fange det selvfølgelige og det ikke-selvfølgelige, det bevidste og det ubevidste og dermed skabe en forståelse. Det kan lade sig gøre, fordi verden mødes med en åbenhed og en fordomsfri tilgang (Hastrup 2002). Tilsvarende åbenhed er tilstræbt i dette casestudie, hvor hver informant observeres i løbet af sin arbejdsdag - henholdsvis en formiddag eller en eftermiddag. For at få størst mulig variation og spredning i det empiriske materiale var de fire informanter udvalgt, så de havde deres personlige plads forskellige steder i kontormiljøet, tilhørte forskellige teams og arbejdede med meget forskellige arbejdsopgaver. Derudover bestod feltarbejdet af stedobservation (Grangaard 2008), hvor jeg opholdt mig i kontormiljøets fællesområder en eftermiddag og en formiddag og betragtede rum med aktivitet frem for at se på informantens aktivitet i rum. Alle observationsperioderne blev videofilmet. 


\section{Videoklip skaber spejling og refleksion}

Videomaterialet fungerede ikke blot som en form for feltnotater, men var et materiale, hvorfra der kunne genereres en form for videoportræt (Buur et al. 2000) i redigeringsfasen. Et par uger efter observationsforløbet deltog hver informant $i$ et dialogmøde. Informanternes ekspertrolle (Lindahl 2001) blev aktiveret ved deltagelsen i dialogmøderne. Ved dialogmødet blev informanterne præsenteret for et antal videoklip fra observationsperioden og to opgaver: bølgeøvelse og interaktion+autonomiøvelse ${ }^{2}$.

Formålet med fremvisningen af videoklippene handlede både om godkendelse, men også om etablering af en spejling og en fælles platform for resten af dialogmødet tilsvarende i designdialogernes indledende workshop (Fröst 2004). Som når man kigger i et spejl og bogstavelig talt ser sig selv, fungerede videoklippene som et spejl, der spejlede informanternes aktivitet, og den situation aktiviteten foregik i med hensyn til deltagere og sted.

Designspil med spilleplade, spillebrikker og spilleregler er et middel til facilitering af en brugercentreret designproces. Modsat andre spil gælder det ikke om at finde en vinder, men derimod at afprøve og udforske det pågældende design (Brandt \& Messeter 2004). Det var ønsket at skabe individuel refleksion hos den enkelte informant gennem at involvere informanten i øvelser inspireret af designspil. På baggrund af videoklippenes spejling fik hver informant mulighed for at se sig selv med nye briller i opgaverne og på en ny måde italesætte arbejdsdagen og brugen af kontormiljøet. Tilgangen i dette casestudie kan karakteriseres som intervenerende, idet jeg udover at opholde mig i feltet også designer en anledning i form af dialogmødet. Her skabes dialog og et refleksionsrum, hvor spejling og informantens oplevelse og besvarelse både var hinandens forudsætning og en gensidig berigelse.

\section{Samarbejde med tegnestue i et undersøgelsesforløb}

Løbende i ph.d.-forløbet diskuterede jeg projektet med en partner fra tegnestuen $\mathrm{T} 2$, som var meget interesseret $\mathrm{i}$, hvordan det var muligt at spejle medarbejdernes aktivitet og brug af rum. T2 var i 2006/2007 rådgiver for en stor dansk offentlig organisation kaldet RS. RS var fusioneret af tre organisationer og fysisk placeret i et eksisterende kontorhus med eksisterende inventar. Ledelsen i RS's personaleafdeling, HR, ønskede en mere åben indretning af det område, de var blevet tildelt, for at understøtte videndeling og samarbejde. Med $\mathrm{T} 2$ som rådgiver, igangsatte ledelsen $\mathrm{i} \mathrm{HR}$ derfor et pilotprojekt med krav om, at medarbejderne skulle involveres i processen.

Med pilotprojektet blev der skabt en mulighed for, modsat en traditionel proces, i den indledende fase at udvikle og afprøve en involverende forundersøgelse med intentionen dels om at skabe et billede af organisation, som var fælles for alle parter, men også at undersøge om det var muligt at udvikle redskaber til arkitektens værktøjskasse. Forundersøgelsen blev en case i et ph.d.-projekt om dialogorienteret registrering af samspil mellem rum og aktivitet.

Jeg var ansvarlig for udviklingen og udførelsen af dialogorienteret registrering $i$ dialog med T2-partneren og en sagsmedarbejder. Det var vigtigt at give T2 en oplevelse af denne involverende undersøgelsestilgang. Derfor deltog sagsmedarbejderen i en informantobservation, og begge deltog hver især i et dialogmøde. På et overordnet niveau har jeg - ved at gennemføre dialogorienteret registrering og gøre den tilgængelig for både HR som bygherre og arkitekten som rådgiver - spillet et bidrag ind i pilotprojektet og dermed medvirket i en forandring af den ellers kendte praksis.

På workshop 1, som T2 afholdt i HR inden fusionen trådte i kraft, introducererede 
jeg medarbejderne til den involverende undersøgelsesform og dens videofilmede observationer ved at vise eksempler på videoklip fra et kontormiljø for at give dem en fornemmelse af, hvad det handlede om. Efterfølgende udvalgte HR de fire informanter: Konsulenten Ole sad i et åbent miljø og arbejdede i dialogteamet, personalekonsulenten Inge havde sit eget kontor i lønteamets område, mens sagsbehandleren Trine havde sin personlige plads i et dobbeltkontor. Juristen Lene fra jurateamet sad også i et dobbeltkontor, men i en anden fløj.

\section{Udvikling af bølger som begreb}

I de foregående cases udarbejdede jeg i den indledende redigeringsfase en videolog $i$ tekstform for at skabe overblik over videomaterialet. Særlig efter at have fulgt informanten Inge og oplevet alle hendes skift i aktivitet og sted, oplevede jeg et behov for at få skabt en langt mere overskuelig kortlægning af forløbet med dets skift i forhold til tiden. Resultatet blev logskemaet, som var en direkte kortlægning og grafisk afspejling af en informantobservation. Informantens aktivitet og det sted, hvor aktiviteten foregik, blev gengivet minut for minut i en form, som kunne minde om mønsteret i en strikkeopskrift. Hver aktivitet fik en signatur i form af en farve, ligeledes som der blev skelnet mellem, hvorvidt informanten selv igangsatte en aktivitet eller ej. Eksempelvis betød pink, at informanten selv ringede i telefon, mens lyserød fortalte, at informanten blev ringet op. De uformelle møder opdeltes i seks typer, alt efter om informanten selv tog kontakt eller blev kontaktet, samt om der var tale om kollega i nærmiljøet eller ej. Eksempelvis havde samboer i et dobbeltkontor en anden farve end en kollega fra en anden del af kontormiljøet. Aktiviteter som afhentning af post og fotokopiering havde også deres egne farver. Eftersom et minut kunne omhandle et skift mellem to aktiviteter, udarbejdede jeg en struktur i logskemaet, som viste både skift, og når lignende aktiviteter foregik i forlængelse af hinanden. Eksempelvis når en telefonsamtale blev afløst af en ny telefonsamtale.

Observationsforløbene for Ole og Inge

Illustration 1. Logskemaer med henholdsvis store og små bølger: Ole og Inge.
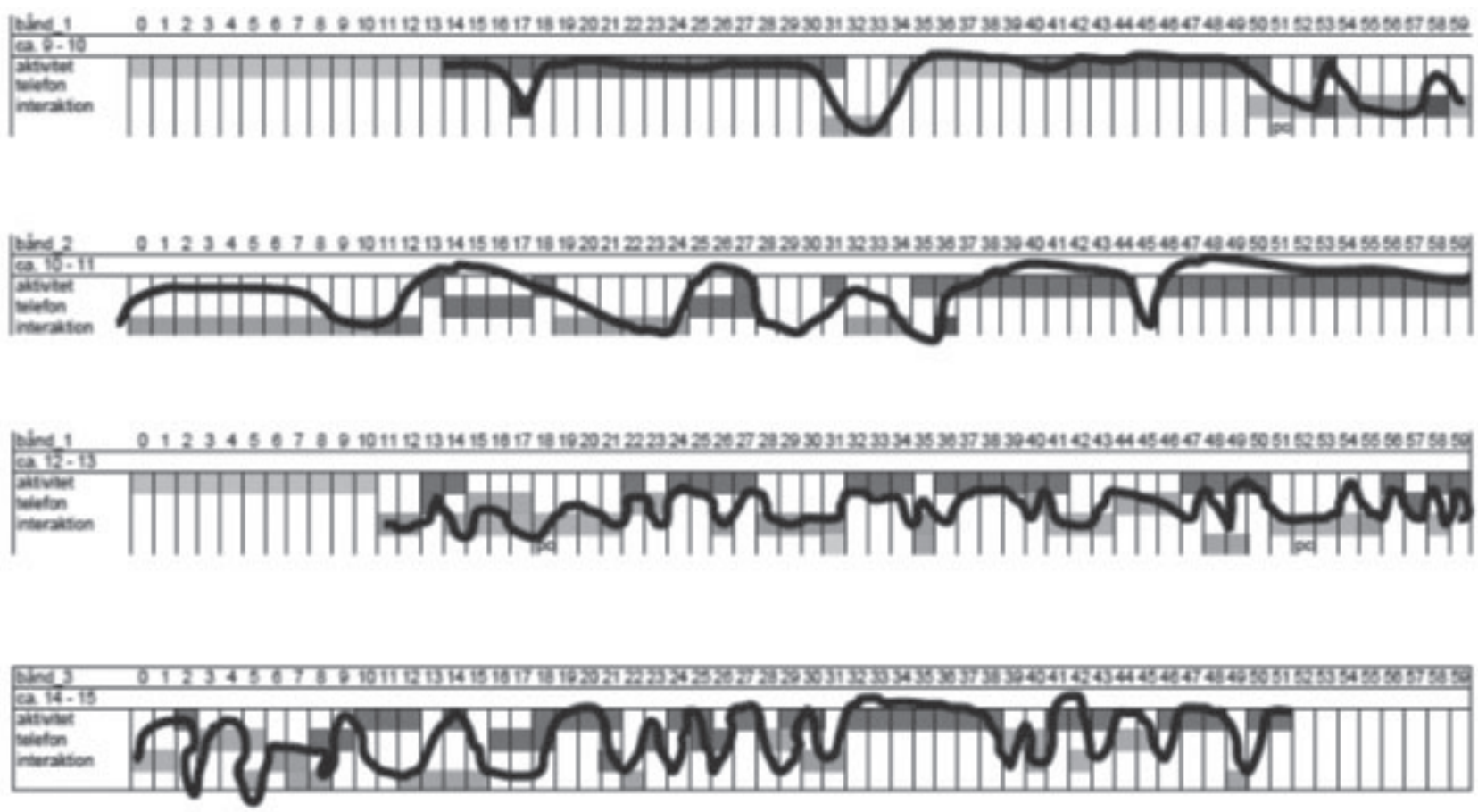
var de første, og de var meget forskellige. Ole havde perioder med den samme aktivitet, mens Inge ofte blev afbrudt i sin aktivitet eller selv skiftede aktivitet. Disse skift i aktivitet viste sig bogstaveligt talt i logskemaerne. Der var perioder, hvor Inge og også Trine knapt nåede at lægge røret på, førend telefonen ringede igen. I en periode aftalte Trine med sin sambo Iben, at Iben trak Trines telefon, så hun selv kan få lidt ro. Mens Iben tog sig af et opkald til Trine, ringede Trines telefon alligevel.

Egentlig var logskemaet oprindelig tænkt som et internt arbejdsredskab til brug ved udvælgelsen af videoklip. Mens jeg sad og kiggede på udprint af disse logskemaer med en pen i hånden, opdagede jeg, at man kunne tegne forbindelser mellem farvefelterne ved hvert skift i aktivitet, og der opstod en bølgebevægelse. Bølgebevægelsen fortalte både, at der var tale om et skift, men fortalte også om intensiteten, om en aktivitet varede et stykke tid eller skiftede hurtigt. Bølgerne blev en metafor for rytmen i løbet af en arbejdsdag. Jo flere skift desto flere små bølger og korte perioder med samme aktivitet og jo færre skift og dermed længere perioder med samme aktivitet, desto større bølger. Betegnelserne puls og frekvens var under overvejelse, men jeg valgte at holde fast i bølge som begreb. Det var vigtigt at undgå eventuelle konnotationer, som kunne skabe misforståelse eller antyde en værdiladning. Med bølgebegrebet blev det muligt at beskæftige sig med et længere forløb som helhed frem for nedslagspunkter.

\section{Rytme - et kendt begreb}

I et studie af viden på et hospital er rytme det begreb, der gør det muligt at forstå arbejdspraksis som helhed. Der defineres to hovedtyper af rytme: de fintkornede rytmer og rytmer i stor skala. Morgenrunde er rytme i stor skala, mens at vente på et laboratoriesvar hører under de fintkornede rytmer.
Dobbeltrytmer, når to rytmer ikke stemmer overens, skaber udfordringer, der kan ende i en konflikt. For at være i stand til at tage beslutninger inddrager og vurderer personalet løbende forskellige former for viden. Disse processer er sammenvævet med personalets arbejdsopgaver og dermed også med alle rytmerne. Derfor fungerer rytmerne som kilde til at lede og koordinere arbejdet på hospitalet (Reddy \& Dourish 2002).

Bæredygtige rytmer anvendes som begreb til at karakterisere rytmen på arbejdspladsen, hvor både medarbejdere og fællesskabet har indflydelse på tidsmiljøet. Målet er at skabe en balance mellem det kontrollerede og repeterende tidsmiljø og det grænseløse tidsmiljø præget af et fravær af kontinuitet. Studier af to industrielle fremstillingsvirksomheder, to grundskoler og to konferencecentre har genereret syv nøglefaktorer. For at kunne skabe bæredygtige rytmer på en arbejdsplads skal der være en opmærksomhed til stede omkring disse nøglefaktorer (Holt et al. 2013).

Hvor det ene studie peger på behovet for en opmærksomhed på rytme for at kunne forstå arbejdspraksis, udfolder det andet studie en palet af nøglefaktorer, der også kan fungere som hjælp til at kortlægge arbejdspladsens forskellige rytmer. Ingen af studierne beskæftiger sig med det aspekt af rytme, der handler om medarbejderens oplevelse af rytme, eller hvorledes det kan lade sig gøre at lade medarbejdere udtale sig. Velvidende at der kan være mange rytmer til stede, var det i studiet hos HR intentionen at fokusere på den enkelte medarbejders oplevelse af rytme i løbet af en arbejdsdag parallelt med udviklingen af et grænseobjekt, der kunne formidle denne oplevelse.

\section{Dialogmødets bølgeøvelse}

I et andet dansk workspace-forskningsprojekt fik de involverede medarbejdere to og 
to til opgave at tegne, hvordan de oplevede rytmen i løbet af en dag, en uge og et år (Binder et al. 2008). Samme selvdokumenteringsfunktion havde bølgeøvelsen ved dialogmødet, idet informanten fik til opgave at beskrive bølgebevægelser, som observationen ikke omfattede: henholdsvis en dag, en uge og en måned. En væsentlig forskel ved min øvelse var introduktionen af bølgebegrebet som redskab til at formulere sig omkring oplevelsen af arbejdsdagen.

\section{Lene tegner bølger}

"Jeg introducerer bølgemetaforen og forklarer Lene, at hun nu selv skal tegne bølgebevoegelser. For at hjoelpe Lene i gang, tilføjer jeg, at hun kan begynde med at markere begyndelsestidspunktet, hvis hun eksempelvis møder på det samme tidspunkt hver dag. Lene ser, at hendes arbejde alene ved pc'en kan beskrives med en bølgetop og andre aktiviteter og afbrydelser med bølgedal. Hun fortoeller, at det var lidt påfaldende, at hun på observationsdagen ikke deltog i møder. Jeg forklarer, at faste formelle møder, og hvad Lene ellers ser af møder i løbet af en uge, skal tegnes ind på øvelsespladen."

"Derefter kigger hun på linjen over en uge og fortoeller, at der er et fast møde mandag formiddag. Lene stopper op og forklarer, at hun ikke kan beskrive ugen i detaljer. Jeg spørger om, hvad hun kommer til at toenke på, når hun toenker på sin uge. Om den føles hektisk, mens jeg viser en bevaegelse med mine hoender, eller om ugen begynder stille og roligt, men bliver mere hektisk mod fredag, eller om der er tale om en jaevn bevaegelse, hvor dagene er ens, men stadig har den daglige bølgebevoegelse, som hun lige har tegnet. Lene synes, det er svaert, og jeg foreslår, at vi vender tilbage til ugens rytme senere og $i$ stedet kigger på månedens bevaegelse. Lene mener ikke, at der er nogen forskel i løbet af en måned, som der ville vaere i et lønkontor.
Det virker, som om Lene har siddet og toenkt imens, for pludselig griber hun pennen og begynder at pege på aksen over en uge. Samtidig forklarer hun: 'At der vil voere mange afbrydelser om formiddagen og tid til at arbejde om eftermiddagen'. Jeg spørger, om der egentlig er tale om skift $i$ løbet af formiddagen og laegger en klar plastfolio over tirsdagen. Herefter tegner jeg en bølgebevoegelse med små bølger og spørger Lene, om hun ser det sådan, hvilket hun gør."3

\section{Bølger skabte genkendelighed}

Alle var overraskede over at se logskemaets grafiske komprimering og samtidig forundrede over, at det var lykkes en fremmed at se og fremvise en genkendelig gengivelse. Inge og Trine, begge med observationsperioder karakteriseret af små bølger, var særlig overraskede over at se, at der faktisk var tale om så mange skift i aktivitet, da de begge huskede observationsperioden som forholdsvis rolig sammenlignet med andre dage.

Oles dag består i logskemaet af store bølger. Han fortalte, at fremover ville det ændre sig. Han ville få flere telefonsamtaler, men samtidig også være mere ud af huset i forbindelse med konferencer og undervisning. Lenes logskema mindede om Oles, men i bølgeøvelsen viste det sig, at hun havde flere formelle møder hver dag. Ligeledes havde hun formiddage og dage i løbet af ugen, som kunne beskrives med små bølger. Inge havde også formelle møder i løbet af ugen. Inge, Trine og Lene oplevede alle, at dagen ofte blev afsluttet med en stor bølge, hvor der var ro til alenearbejde.

\section{Rummets rolle i bølgerne}

Det var mit ønske at inddrage rummets rolle, eftersom bølgerne var situeret i det fysiske kontormiljø. En bevidsthed omkring arbejdsdagens aktiviteter og skift herimellem bør ikke isoleres fra en bevidsthed om, hvordan kontormiljøet understøtter aktivi- 
teten. Med udgangspunkt i de tegnede bølgebevægelser fik informanten til opgave at vurdere rummets rolle som medspiller eller modspiller i forhold til henholdsvis aleneaktivitet og gruppeaktivitet, repræsenteret af små cirkulære klistermærker i fire forskellige farver.

Inge var glad for sit enkeltkontor og opfattede det som en medspiller uanset typen af aktivitet. Trine satte et hvidt klistermærke på sin bølgebevægelse, da hun syntes, at dobbeltkontoret var en medspiller for hendes aktivitet i løbet af dagen, selvom samboen talte i telefon eller havde besøg. Lene var enig med Trine, men fandt alligevel, at det kunne være vanskeligt ind imellem at koncentrere sig om alenearbejdet. Dobbeltkontoret spillede en rolle som både medspiller og modspiller. Det gjaldt ikke kun alenearbejde, men også i forhold til gruppeaktivitet. Lene fortalte, at det fungerede fint, når både samboen og hun selv havde besøg, mens det kunne være vanskeligt, når hele teamet mødtes. Jeg spurgte ind til deres behov og tænkte selv på store tavler og andet 'brainstorm'-udstyr, men det viste sig, at behovet primært handlede om at få ro og undgå forstyrrelse fra kollegaer uden for teamet. Under vores samtale tilføjede Lene, at de jo selvfølgelig kunne lukke døren, men de oplevede, at det var vigtigt at signalere åbenhed i form af den åbne dør. Ole betragtede grundlæggende det åbne kontormiljø som en modspiller, og han drømte om at få et enkeltkontor. Han satte et blåt klistermærke på bølgebevægelsen og fortalte, at det ikke var muligt at tale $i$ telefon, uden at andre kunne høre det, og at han derfor gik ud på gangen for at tale $\mathrm{i}$ telefon. Endvidere blev han forstyrret af de uformelle møder i naboteamet modsat interaktion i hans eget team, som han fandt relevant. Han tilføjede et gult klistermærke, da han savnede mødefaciliteter tæt på den personlige plads, og derfor blev rummet en modspiller i forhold til gruppeaktivitet. Han forklarede, at hvis han sad tættere på kompetenceteamet, der sad en i en anden fløj, ville rummet også kunne blive en medspiller. Herefter klistrede han et sort klistermærke på bølgebevægelsen.

\section{Alle medarbejderne i HR deltog i bølgeøvelse}

Ved workshop 2 blev alle medarbejdere indledningsvist præsenteret for logskemaer og videoklip fra observationerne i forbindelse med min fremlæggelse af, hvad jeg havde set hos dem. Det var ikke dem selv, der blev observeret, men det var deres kollegaer og deres eget miljø. Dernæst fortalte jeg om dialogmødernes opgaver. Både for at orientere medarbejderne, men også for at introducere bølgebegrebet. Her gennemgik jeg Inge og Lenes besvarelse med henholdsvis små og stor bølger samt kombinationer.

Alle medarbejderne fik derefter til opgave at interviewe sidemanden om oplevelsen af den daglige bølgebevægelse. Det var op til dem selv, om de ville tegne eller beskrive bølgebevægelsen i tekst. En medarbejder rakte hånden op og spurgte, om det var tilladt også at beskrive den bølgebevægelse, man drømte om. På dialogmødet havde Ole formuleret en fremtidig bølgebevægelse. Eftersom fokus i wokshoppen var initiering af spejling, var jeg ikke gået videre med det fremtids- og forandringsperspektiv, der faktisk lå som en mulighed i bølgebevægelsen.

Jeg er taknemlig for, at spørgsmålet blev stillet, for det viste sig, at ud af de 37 deltagere, var der 15 inklusiv chefen, som ønskede en anden bølgebevægelse i arbejdsdagen. Derudover var der to, som så for sig, at deres bølgebevægelse ville ændre sig i takt med udviklingen i teamets opgaver. Det betød samtidig, at der var en del medarbejdere, som ikke så noget behov for ændringer, de var tilfredse med deres egen bølgebevægelse. 
Illustration 2. De syv bølgetyper i HR.

\begin{tabular}{l|c|c}
$\begin{array}{l}\text { De } 37 \text { besvarelser kan kategoriseres i syv forskellige typer af } \\
\text { bølgebevagelser }\end{array}$ & $\begin{array}{l}\text { Ingen kommentar } \\
\text { Ønsker forandring }\end{array}$ \\
\hline Små bølger & 3 & 6 \\
\hline Små bølger og en stor sidst på dagen & 3 & 2 \\
\hline Stor bølge først på dagen, små bølger og en stor bølge sidst på dagen & 1 & 1 \\
\hline Små bølger og perioder med store bølger & 3 & 3 \\
\hline En kombination af stor bølge og nogle små bølger, gentages i løbet af dagen & 3 & 1 \\
\hline Stor bølge og perioder med små bølger & 5 & 2 \\
\hline Store bølger & 2 & 2
\end{tabular}

* forventer ændring grundet udviklingen i teamets opgaver.

\section{Et fælles sprog hos HR}

Med bølgebegrebet fik HR et sprog til at tale om, hvordan de oplevede deres arbejdsdag samt vurdere, om de var tilfredse med den. Når de talte sammen nu, var det med udgangspunkt i ny viden om dem selv. Viden, som de selv havde været med til at skabe. Denne viden skabte en kollektiv bevidsthed i organisationen om, hvem de var. Det blev synligt for at alle, at arbejdsformen varierede, fordi opgaverne var forskellige, og dermed var medarbejdernes roller også forskellige.

Samtidig oplevede de, at de til trods for forskelligheden også havde fælles træk. Nogle oplevede ofte at blive forstyrret og ønskede derfor en anden bølgebevægelse, mens andre var fælles om at være tilfreds med rytmen i arbejdsdagen. De fik tillige anledning til at tænke over, hvad det betyder, når man afbryder andre. Billedet af dem selv besad nu en klarhed, de ikke tidligere havde kendt til.

På eget initiativ integrerede HR bølgerne i deres LEAN-projekt. Når ledelsen oprindelig ønskede at rive vægge ned for at understøtte samarbejde og videndeling, kan det tolkes som, at de faktisk ikke var klar over, at interaktion og videndeling forekom hele tiden som små og store bølger, samtidig som medarbejderne egentlig oplevede at mangle mere tid og ro til alenearbejdet. Det blev også synligt for alle, at de fysiske rammer optrådte med varierende rolle alt efter situationen, et enkeltkontor var nødvendigvis ikke ensbetydende med ro, hvis telefonen ringede uafbrudt, eller man fik mange besøg.

\section{Anden løsning end forventet}

Baseret på en helt ny bevidsthed, 'situational awareness', fik HR og T2 adgang til et fælles billede af HR og hverdagen i HR. Dermed fik de også et fælles udgangspunkt for at diskutere kontormiljøet.

'Post-Occupancy Evaluation', forkortet POE, er en evaluering af bygningen, efter den er taget i brug. Læsningen af samspillet mellem HR og kontormiljøet kan betragtes som en POE i et predesignperspektiv, hvor evaluering af en eksisterende situation danner baggrund for et fremtidigt redesign. Der er større chance for, at der følges op på problemstillinger afdækket i en POE, hvis organisationens medlemmer selv har været involveret (Wener 1988). Det var de 
hos HR, og foreløbigt prioriterede ledelsen at igangsætte tre initiativer: 1) 'callcenter'funktion for at skabe en ny telefonkultur og give medarbejderen perioder uden telefonopkald, 2) et fælles caféområde for at få skabt et fælles mødested og 3) forbedring af de akustiske forhold i det åbne miljø. Det resulterede i helt andre løsninger, end de involverede parter havde forventet, da de gik i gang med pilotprojektet. $\mathrm{Nu}$ var udgangspunktet et reelt kendskab til organisationen og medarbejdernes arbejdsform frem for en forestilling om, hvem de var, og hvilke behov de havde.

\section{Bølgernes plads i værktøjskassen}

Grundlæggende er bølgerne meget enkle, og i princippet kræver de ingen forberedelse. De kan tegnes i luften med en pegefinger, i sandet med en pind eller på en serviet med en pen. På den baggrund kan de let tage plads i værktøjskassen.

\section{Arkitektens modtagelse af bølgerne}

Ved en senere præsentation af dialogorienteret registrering for alle medarbejderne hos T2 var det tydeligt, at de blev tiltalt af den involverende tilgang og særlig dialogmødets spejling.

"Utroligt spoendende og en utrolig måde at kunne skabe noget, som rigtig passer til dem, og ikke kun skabe noget til de, de tror, at de er. Nogle gange kan man godt have den oplevelse, når man interviewer, selvom interviewsituationen har voeret fin, og forløbet har voeret, som det skal voere, at de ikke helt evner at svare rigtigt på det. Der kan man jo se sig til, hvad der sker - på en helt anden måde" (T2-medarbejder 1).

"De svarer på deres overbevisning og ikke på, hvad der virkelig foregår. Og det er jo det: at kunne blive ved med at spørge ind under.
Hvor her er det oplagt, her kan de se det selv" (T2-partner).

"Noget af det samme, som jeg toenkte på. Netop når man interviewer, så er det ikke altid, at de kan forestille sig, hvordan tingene kan voere bedre, fordi de ikke altid kender sig selv godt nok" (T2-medarbejder 2).

T2-medarbejderne gav udtryk for, at de ville ønske, at de havde haft disse redskaber til rådighed på dette tidlige stadie $\mathrm{i}$ andre projekter. De mente, at organisationerne og medarbejderne i kraft af denne nye forståelse af sig selv blev klædt bedre på til den proces, som T2 normalt igangsatte og faciliterede. Når denne forståelse manglede i forbindelse med behovsafdækningen, var der en risiko for, at medarbejderne blot svarede ud fra en overbevisning om, hvordan de arbejdede, frem for en bevidsthed om, hvordan hverdagen faktisk forløb. Med bølgerne og logskemaet som redskab blev der skabt en gengivelse af hverdagen i kontormiljøet, alle kunne forholde sig til. T2-partneren lagde desuden vægt på forandringsperspektivet ved bølgeøvelsen.

"Det som var rigtig fantastisk, at de begyndte at tale om, hvordan de gerne ville have, at det skulle voere. De bevoegede sig fra bare at acceptere, at deres dag var på en given måde, som de kunne sidde og småbrokke sig over, til pludselig at blive proaktive og sige: Hvad skal jeg gøre for at få det sådan her i stedet for?" (T2-partneren).

Der opstod et læringsrum hos T2, hvor de så på deres egne metoder og projekter med nye briller, samtidig med at de begyndte at tale om og reflekterede over den situation, deres kunder normalt befandt sig i. Det var som om, der opstod en større forståelse for de mennesker, der designes til samt et ønske om at få fokus på dem og deres hverdag. 


\section{Tidskrævende proces}

Dialogorienteret registrering i denne case var en tidskrævende proces blandt andet på grund af det store udviklingsarbejde.

"Man vil aldrig få en kunde til at betale for dette, det er så svoert at saelge vaerdien af det inden. Men den voerdi, det har haft for HR, den synes jeg er ret åbenlys, og det kan de også godt se, men der ligger den afbalancering af, hvordan man kan nå til det her resultat uden den store tidsmoessige investering. Kan vi skabe erkendelse på baggrund af nogle andres erkendelse?" (T2-partner).

T2-partneren stiller et relevant spørgsmål. Hvorvidt erkendelse skabes på baggrund af en erkendelse, andre har opnået? Hos HR skabes et erkendelsesrum, da alle medarbejderne involveres $i$ at se sig selv og udtrykke oplevelsen af egen arbejdsdag. Efterfølgende taler de om arbejdsdagen på en helt ny måde, fordi de har fået et sprog og set sig selv på en ny måde. Lader det sig kun gøre, fordi de forinden præsenteres for videoklip fra deres eget miljø? Eller ville det samme have fundet sted på et andet grundlag med en palet af videoportrætter fra andre kontormiljøer eller andre midler? Dermed kunne processen komprimeres, fordi der blev skabt en genvej til spejlingen.

Det vil være muligt at komme omkring mange tematikker med forskellige genveje til spejlingen. Der ligger dog en fare i at præsentere en organisation for en palet af videoportrætter eller profiler i en eller anden form. Dermed glemmer man at være åben og stille spørgsmål. I stedet presses medarbejderne ind i et antal profiler frem for at man får skabt et reelt fælles billede af organisationen. Francis Duffy har lanceret visionen om 'new office', det aktivitetsbaserede kontordesign, hvor forskellige typer arbejde alt efter graden af selvbestemmelse og kontakten med andre understøttes af fire forskellige typer af indretning (Duffy 1997). Der har inden for kontorindretning været en tendens til at fokusere meget på disse fire typer og ukritisk vælge en type uden at inddrage forløbet $\mathrm{i}$ en arbejdsdag (Grangaard 2008).

Dog skal man ikke se bort fra, at det får en særlig betydning, at jeg har set HR og formidler det sete til dem. Et kompromis mellem undersøgelsestilgange kunne være forskellige præfabrikerede spejlinger, men ud fra en opmærksomhed på dynamikken i arbejdsdagen i form af bølgerne, som uanset tilgang kan være et supplerende redskab.

Det vil være interessant at undersøge problemstillingen nærmere.

\section{Bølger er grænseobjekter}

Bølger som begreb og som øvelse er grænseobjekter kendetegnet af de fire wengerske karakteristika. Bølgebevægelsen besidder 'modularitet', for der kan knyttes flere perspektiver til. Det grundlæggende sæt af perspektiver er de store bølger og de små bølger. De optræder som to forskellige moduler, der kan sættes sammen i et utal af kombinationer. Medarbejderne i HR formulerede på baggrund af disse moduler syv forskellige bølgebevægelser. Det kan nemt lade sig gøre at besvare opgaven ud fra forskellige perspektiver, den nutidige, den fremtidige eller den ønskede bølgebevægelse. Der ligger i standardiseringen tre grundlæggende muligheder i denne basale bølgeøvelse, som kan betragtes som en rækkefølge, hvor de bygger ovenpå hinanden. Bølgerne er ligeledes karakteriseret af tilpasningsevne, for det er muligt at aflæse og gengive en bølgebevægelse uanset arbejdsform eller fysisk miljø. Samtidig er det også muligt at besvare øvelsen på forskellig måde, i tegning eller i tekst. Overordnet befinder bølgerne sig på et abstrakt niveau, da de er en abstraktion af rytmen i arbejdsformen. 


\section{Bølgernes potentiale}

Som bølgebevægelsen hidtil har fungeret, har størrelsen af hver enkel bølge været bestemt af, hvor længe den pågældende aktivitet foregår. Den første aktivitet tegnes som en bølgetop, der ved næste skift i aktivitet efterfølges af en bølgedal og så fremdeles. På dette overordnede niveau handler det udelukkende om skift i aktivitet, ikke typen af aktivitet eller hvem, der skaber skiftet.

I forbindelse med dialogmødets bølgeøvelse spørger Lene, om 'oppe' betyder alenearbejde, og 'nede' betyder afbrydelse? Hun hentyder til bølgetop og bølgedal. Lenes spørgsmål indikerer, at man kan tolke bølgerne på flere måder og dermed i endnu større grad beskæftige sig med forskellige perspektiver.

I bølgeøvelsen kunne man lade bølgerne udspænde mellem to typer af aktivitet, hvor der eksempelvis er tale om forskellige former for selvbestemmelse. Hvis vi forestillede os, at man bad medarbejderne om at beskrive relationen mellem alenearbejde og afbrydelse, var der tale om et detaljeret niveau, hvor man zoomede ind på en specifik tematik. Der ligger derfor muligheder i bølgebegrebet i forhold til forskellige tidspunkter eller faser i en proces. Den basale bølgeøvelse i en indledende fase og måske senere følge op med en bølgeøvelse, der tager en specifik tematik op.

\section{Behov for uformel facilitering}

Når Lene besvarede bølgeøvelsen ved dialogmødet, var der tidspunkter, hvor hun fandt det vanskeligt enten at gå i gang eller komme videre. Der gik jeg ind som facilitator og hjalp hende. Første gang skaber jeg en indgang til øvelsen ved at bede hende om at forholde sig til noget konkret. Jeg bruger mine hænder til at tegne bølgebevægelse i luften for at få hende sporet ind på bølgebegrebet. Senere gør jeg brug af den mulighed, som øvelsen giver for at hoppe lidt i opgaven og dermed skifte skala, hvilket senere resulterer $i$, at Lene selv vender tilbage til den del, som var vanskelig at besvare. Jeg viser hende på klar plastfolie, hvordan man på baggrund af det, hun fortæller, kan tegne bølger. Herefter foreslår jeg hende, at hun reviderer den første besvarelse, som i min optik ikke var en endelig besvarelse. For informanterne er det en uvant situation at skulle forholde sig til bølgerne i deres egen arbejdsdag og samtidig tegne. Heldigvis er de gode til at spørge, når de er i tvivl. Eksempelvis spørger Ole, hvordan han viser, at han er ude af huset en hel dag. Vi taler sammen inden bølgerne tegnes, undervejs, og når informanterne af sig selv fortæller om deres arbejdsdag. De forskellige måder, hvorpå informanten guides videre $\mathrm{i}$ besvarelsen, er ikke en del af de formelle instrukser defineret i øvelsen, men de opstår omkring øvelsen mellem facilitator og informant. Når 'facilitator stages and guides' og 'rules and instructions' fremhæves som karakteristika ved grænseobjektets kontekst (Broberg 2010), vil jeg tilføje, at det er muligt at tale om to niveauer: det formelle og det uformelle. I relation til det uformelle niveau bør man nok være opmærksom på, at der ligger indlejret en palet af strategier - forskellige måder, hvorpå facilitatoren næsten ubemærket kan coache informanten igennem øvelsen. I de situationer er der på flere planer tale om tilnærmelsesvis 'reflection-in-action'-situation (Schön 1983). Informanten reflekterer gennem at tegne, mens facilitatoren reflekterer gennem $1 \varnothing$ bende at aflæse og vurdere informantens behov for hjælp til at komme videre. Man kunne mene, at dette behov for uformel facilitering skyldes, at standardiseringsaspektet ikke er udviklet tilstrækkeligt. Her er det vigtigt at huske, at informanterne ikke er vant til at tegne. De befinder sig derfor i en uvant og ny situation, hvor de skal forholde sig til mange informationer og begreber. 


\section{Udviklingspotentiale i integrering af kontekst}

Der ligger i bølgeøvelsens anden del et udviklingspotentiale. Hos HR fik informanterne med udgangspunkt i aktiviteten til opgave at tage stilling til rummets rolle og dermed anledning til at se på rummet med andre briller. Når Ole beskrev, hvad der skulle til, for at rummet blev en medspiller, reflekterede han med udgangspunkt i bølgerne over, hvad der skulle til, for at kontormiljøet kunne virke understøttende for aktiviteten. Alt efter typen af projekt ville det være relevant at spørge til temaer, der knytter sig til SOFT-modellens 'space', 'organisation', 'finance' og 'technology' (Horgen et al. 1999) - eksempelvis kultur, ledelse, samarbejde og telefonsystem. Bølgerne skaber en indgangsvinkel til at vurdere forskellige aspekter af kontormiljøet og organisationens virke, som i kraft af disse nye vinkler kan tilvejebringe problemstillinger og viden, scenarier eller tanker om løsninger, der ellers ikke har været italesat tidligere. Som med rummets rolle skabes en anledning til at opleve og italesætte kompleksiteten i kontormiljøet og organisationen, og dermed vil diskussionen af designløsninger kvalificeres, når fordele og ulemper diskuteres på baggrund af bredere grundlag.

\section{Mere tid til begrebet}

Forløbet med dialogorienteret registrering hos HR forløb over en periode på halvanden måned. Der var derfor tale om et komprimeret forløb med mange delopgaver undervejs. Samtidig var det også et meget dynamisk forløb præget af en god energi både i samarbejdet med $\mathrm{T} 2 \mathrm{og}$ i relation til HR. Det var ærgerligt, at denne case var den sidste i ph.d.-projektet. For det ville have været interessant at undersøge brugen af bølgebegrebet og bølgeøvelsen både i sin enkle form og på et mere detaljeret niveau i forbindelse med andre workspace design- processer. Bølgebegrebet er genereret ud af det empiriske materiale uden en større teoretisk ballast. Hvis der havde været mere tid, kunne jeg have arbejdet med bølgebegrebet $i$ en teoretisk retning og udtænkt flere scenarier, inden at det blev afprøvet. Modsat viste begrebet at holde, selvom det blev afprøvet uden et større forarbejde i et forløb kendetegnet af dynamik.

\section{Konklusion}

Bølger, i form af begreb og øvelse, er udviklet på baggrund af observationer af, hvorledes arbejdsdagen forløber for en gruppe medarbejdere i HR. Bølgerne er et udtryk for rytmen i løbet af en arbejdsdag og kobler tidsaspektet med skift i aktivitet. Et skift beskrives i form af en ny bølge. Jo længere periode med samme aktivitet, jo større bølger - og desto oftere en aktivitet skifter, jo flere små bølger.

Bølgerne og bølgeøvelsen er grænseobjekter, der lever op til de fire wengerske karakteristika: modularitet, tilpasningsevne, standardisering og abstraktion. Samtidig har vi set, hvordan bølgeøvelsen indeholder muligheden for at beskæftige sig med forskellige perspektiver i en workspace design-proces.

Bølgebegrebets enkelhed er dets styrke. Det kræver i princippet ingen forberedelse. En bølgebevægelse kan tegnes på en serviet over en kop kaffe. Erfaringen fra HR peger på, at der i faciliteringen af dialogmødet er brug for uformel vejledning undervejs i besvarelsen af bølgeøvelsen, da det er uvant for deltagerne at skulle tegne og forholde sig til dette abstrakte begreb.

Bølgerne får en afgørende betydning for pilotprojektet. For med dialogorienteret registrering og bølgerne som et fælles sprog, skabes der 'situational awareness' og et fælles billede af organisationen hos HR og arkitekten. Bølgerne gør det muligt for medarbejderne at italesætte oplevelsen af 
forløbet i deres arbejdsdag med dens rytme og skift i aktivitet, og dermed lærer organisationen og dens medlemmer sig selv bedre at kende. Samtidig bliver det også med bølgebegrebet muligt at vurdere, hvordan man trives med den aktuelle bølgebevægelse, og hvordan man kunne tænke sig en fremtidig bølgebevægelse. En del af medarbejderne i HR drømmer om en arbejdsdag med flere store bølger for dermed at få mere sammenhængende tid fremfor mange små bølger. Blandt andet handler ledelsen i HR på denne problemstilling og vælger andre løsninger, end de ved pilotprojektets start havde forestillet sig. Det fælles billede kvalificerer beslutningsprocessen.

Med øvelsens anden del om rummets rolle som medspiller eller modspiller får informanterne indblik $i$, at rummets rolle kan variere. Den er ikke statisk. Rollen bestemmes af situationen, den pågældende aktivitet og relationen til de andre medarbejdere og deres placering. Ole udnytter, at det var muligt at udtrykke, hvad der skal til for at få rummets rolle til at ændre sig. Dermed bliver opgaven løsningsorienteret eller scenarieskabende, samtidig med at den skaber refleksion. I denne del af bølgeøvelsen ligger der mange muligheder $\mathrm{i}$ forhold til at vurdere et kontormiljø eller anden form for miljø fra forskellige vinkel og hele tiden i forhold til medarbejdernes arbejdsform og oplevelsen af den.

For de workspace-professionelle er det med bølgerne muligt at kortlægge forløbet og dynamikken i en arbejdsdag samt bringe dette perspektiv med ind i designprocessen frem for udelukkende at se på nedslagspunkter, som det ellers har været almindeligt at gøre.

Med samarbejdet omkring pilotprojektet hos HR har tegnestuen T2 fået udvidet sit repertoire. De kan i princippet nu tilbyde en designproces, der initierer en fælles erkendelse som udgangspunkt for diskussion af behov og løsninger. Bølgerne medvirker til at kvalificere processen. Samtidig tyder deltagelsen i samarbejdet på, at de virkelig har fået øjnene op for medarbejdernes perspektiv og deres arbejdsdag. Dog pegede T2-partneren på en udfordring i forhold det tidsmæssige omfang. Derfor kan man forestille sig, at bølgerne vil optræde som et supplement til eksisterende metoder.

\section{NOTER}

1 Tegnestuen eksisterer ikke længere som DEGW med filialer i hele verden, men er nu blevet en del af den internationale koncern AECOM.

2 Interaktion-autonomiøvelsen behandles ikke i denne artikel. Dette valg må ikke opfattes således, at øvelsen ikke har haft nogen værdi for forundersøgelsen. Men eftersom informanterne på dialogmødet besvarede bølgeøvelsen først, var deres svar uafhængige af denne øvelse.

3 Citat fra beskrivelsen af "Lene tegner bølger" fra (Grangaard 2008).

\section{RefERENCER}

Bakke, John Willy (red.) (2007): A Nordic guide to workplace design, Norge, Telenor research and Innovation/Nordic Innovation Centre. Binder, Thomas \& Eva Brandt (2008): The
Design:Lab as Platform in Participatory Design Research, i Thomas Binder, Eva Brandt \& Judith Gregory (red.): CoDesign, Taylor and Francis , 4, 2. 
Bjerrum, Eva \& Ole Nielsen (2003): Bliver man lidt småsaer af at have sit eget kontor?, Viby J., JP Bøger-Jyllands-Postens Erhvervsbogklub.

Bjerrum, Eva \& Stinne Aaløkke (2005): The office as a strategic artefact for knowledge sharing?, Paper til den 6. international Learning and Knowledge Conference, Trento, Italy.

Blyth, Alistar \& John Worthington (2001): Managing the brief for better design, London $\&$ New York, Spon Press.

Brandt, Eva \& Jörn Messeter (2004): Facilitating Collaboration through Design Games, i Proceedings of the Participatory Design Conference,Toronto, Canada, ACM Press, 121-131.

Broberg, Ole, Rikke Seim \& Vibeke Andersen (2010): Collaborative design of workplaces: the role of boundary objects, i Advances in Occupational, Social, and Organizational Ergonomics, Boca Raton, Taylor \& Francis, 49-58.

Buur, Jacob, Thomas Binder \& Eva Brandt (2000): 'Taking Video beyond "Hard Data" in User Centred Design', i Proceedings of the ParticipatoryDesign Conference, New York, 21-29.

Cuncliffe, Roger \& Santa Raymond (1997): Tomorrow's Office - creating effective and humane interiors, London/New York, Spon Press.

Duffy, Francis (1997): The New Office; with contributions by Kenneth Powell, London, Conran Octopus Limited.

Fröst, Peter (2004): Designdialoger i tidliga skeden - arbetssätt och verktyg för kundenagerad arbetsplatsutforming, Göteborg, Chalmers Tekniska Högskola.

Grangaard, Sidse (2008): Med mennesker i rammen - dialogorienteret registrering af rum og aktivitet i kontormiljøer, København, Kunstakademiets Arkitektskole.

Halse, Joachim et al. (2010): Rehearsing The Future - Sourcebook for userdriven innovation, København, Danmarks Designskoles forlag.
Hastrup, Kirsten (red.) (2002): Ind i verden - en grundbog $i$ antropologisk metode, København, Hans Reitzels Forlag.

Holt, Helle et al. (2013): Et arbejdsliv $i$ acceleration: Tiden og det groenseløse arbejde, Frederiksberg, Roskilde Universitetsforlag.

Horgen, Turid H. et al. (1999): Excellence by Design - Transforming Workplace and Workpractice, New York, John Wiley \& Sons, Inc.

Lindahl, Göran (2001): Rummet som resurs för förandringsarbete, Göteborg, Chalmers Tekniske Högskola.

Marmot, Alexi \& Joanna Eley (2000): Office Space Planning, designing for tomorrow's workplace, New York, McGraw-Hill.

Mosbech, Karen (2003): Arbejdsrummet, organisatoriske mål, fysiske rammer, København, Eget forlag.

Reddy, Madhu \& Paul Dourish (2002): A Finger on the Pulse: Temporal Rhythms and Information Seeking in Medical Work, i Proceedings of $C S C W^{\prime} 02$, New Orleans, Lousiana, USA, ACM Press, nov. 2002, 344-353.

Schön, Donald A. (1983): The Reflective Practitioner. How professionals think in action, England, Ashgate.

Simonsen, Jesper \& Finn Kensing (1996): Using Ethnography In Contextual Design, i Communications of the ACM, juli 1997, 40, 7, 82-88.

Star, Susan Leigh \& James R. Grisemer (1989): Institutional Ecology, 'Translations' and Boundary Objects: Amateurs and Professionals in Berkeley's Museum of Vertebrate Zoology, 1907-39, i Social Studies of Science, 19, 3, 387-420.

Wener, Richard E. (1988): Doing it right: examples of succesful application of environment-behavior research, i The Journal of Architectural and Planning Research, 5, 4, 284-303.

Wenger, Etienne (2004): Praksisfoellesskaber, København, Hans Reitzels Forlag.

Sidse Grangaard, forsker i Universelt design og tilgængelighed ved Statens Byggeforskningsinstitut, SBi, Aalborg Universitet

e-mail: sig@sbi.aau.dk 